\title{
¿論文 A Study on the Strength and Grindability of Granulated Copper Smelting Slag Produced by Water Quenching*
}

\author{
by Hojin RYU ${ }^{1}$, Kazumasa SUGIYAMA ${ }^{2}$ \\ and Fumio SAITO ${ }^{3}$
}

[UDC $669.331 ; 621.745 .58]$

\begin{abstract}
The strength and grindability of copper smelting slag produced by water quenching have been investigated in the framework of single particle crushing and corrective grinding tests. X-ray diffraction analysis clearly indicated that the slag samples are the mixture of glassy and crystalline components, such as fayalite and magnetite. The amount of crystalline component of as-quenched samples increases as the particle size increases. The particle compressive strength of $10 \sim 20 \mu \mathrm{m}$ diameter particles of a sample mainly composed of glassy component appears to be almost twice as high as that of a sample including a large amount of crystalline components.
\end{abstract}

KEY WORDS: Copper Smelting, Slag Particle Compressive Strength, Grindability, X-ray Diffraction

\section{Introduction}

The recycling of industrial waste to useful products is strongly requested for saving our limited natural resources. In this sense, the water-quenched copper smelting slags have recently received attention as a polishing sand for the maintenance of many industrial facilities. Thus, the measurements of basic physical properties such as strength and grindability are necessary for wider applications of this granulated slag. However, little attention has been paid to water-quenched copper smelting slag.

Copper smelting slag mainly consists of fayalite $\left[\mathrm{Fe}_{2} \mathrm{SiO}_{4}\right]$ and magnetite $\left[\mathrm{Fe}_{3} \mathrm{O}_{4}\right]$ with a glassy matrix. The phase compositions of these types of slag, which depend on the quenching condition such as cooling temperature and pressure, are directly related to their physical properties of the present interest. Therefore, this paper describes the first results on the strength and grindability of the water-quenched copper smelting slags coupled with phase characterization by means of X-ray diffraction.

\section{Experimental Apparatus and Procedures}

The copper smelting slag samples produced by water quenching used in this work were taken from the Saganoseki Smelter of Nippon Mining Co., Ltd. Chemical compositions of the slag samples are given in Table 1 together with Bond's work index determined by the standard ball milling method. The size distribution of slag samples is shown in Fig. 1. The photo-micrographs of the polished sections of the present slag samples (Fig. 2) clearly indicate that needle-like fayalite and square-like magnetite crystals exist with the glassy matrix and their percentages correspond to the original sample size. It

\footnotetext{
* Received July 17, 1990: accepted for publication November 28, 1990

$1 \sim 3$. Research Institute of Mineral Dressing and Metallurgy (SENKEN), Tohoku University, Aoba-ku, Sendai 980

1. Visiting Scientist

2. Research Associate, Dr.

3. Associate Professor, Dr.
}

Table 1 Chemical composition and Bond's work index of the copper smelting slag produced by water quenching.

\begin{tabular}{cc}
\hline Chemical composition & mass \% \\
\hline $\mathrm{Cu}$ & 0.59 \\
$\mathrm{Fe}$ & 38.50 \\
$\mathrm{Si}$ & 9.80 \\
$\mathrm{~Pb}$ & 0.15 \\
$\mathrm{Zn}$ & 1.32 \\
$\mathrm{As}$ & 0.09 \\
$\mathrm{Sb}$ & 0.04 \\
\hline Bond's work index & $21.0 \mathrm{kWh} / \mathrm{t}$ \\
\hline
\end{tabular}

is also worth mentioning that the small amounts of spherical copper and copper sulfide are randomly observed in these sections. Therefore, the original granulated slag samples were sieved and classified into the following nine fractions: over $4000 \mu \mathrm{m}, 3360 \sim 4000 \mu \mathrm{m}, 2380 \sim 3360 \mu \mathrm{m}, 1680 \sim 2380 \mu \mathrm{m}$, $1190 \sim 1680 \mu \mathrm{m}, 840 \sim 1190 \mu \mathrm{m}, 710 \sim 840 \mu \mathrm{m}, 250 \sim$ $710 \mu \mathrm{m}$ and under $250 \mu \mathrm{m}$.

Strength measurements of the slag samples were carried out by using a compression testing machine for a small size particle, which enables us to vary compressive load and deformation from 0 to $9.8 \times 10^{-1} \mathrm{~N}$ and 0 to $5 \mu \mathrm{m}$, respectively. The size of a single slag particle in the strength measurement was kept constant between 10 and $20 \dot{\mu} \mathrm{m}$ in diameter which is determined by micro-mesh sieves. The loading rate was kept constant at $6.27 \times 10^{-3} \mathrm{~N} / \mathrm{s}$ so as to be an ordinary loading rate during the measurements of particle compressive strength, so that the single particle fracture is made within a few minute. When a particle is compressed between two parallel platens, the strength of a single particle can be estimated from particle compressive strength, $S t$, defined by the following equation. 1 )

$$
S t=2.8 P /\left(\pi d^{2}\right)
$$

Where, $P$ is the fracture load and $d$ the initial distance between the two parallel platens when a particle is beginning to be 


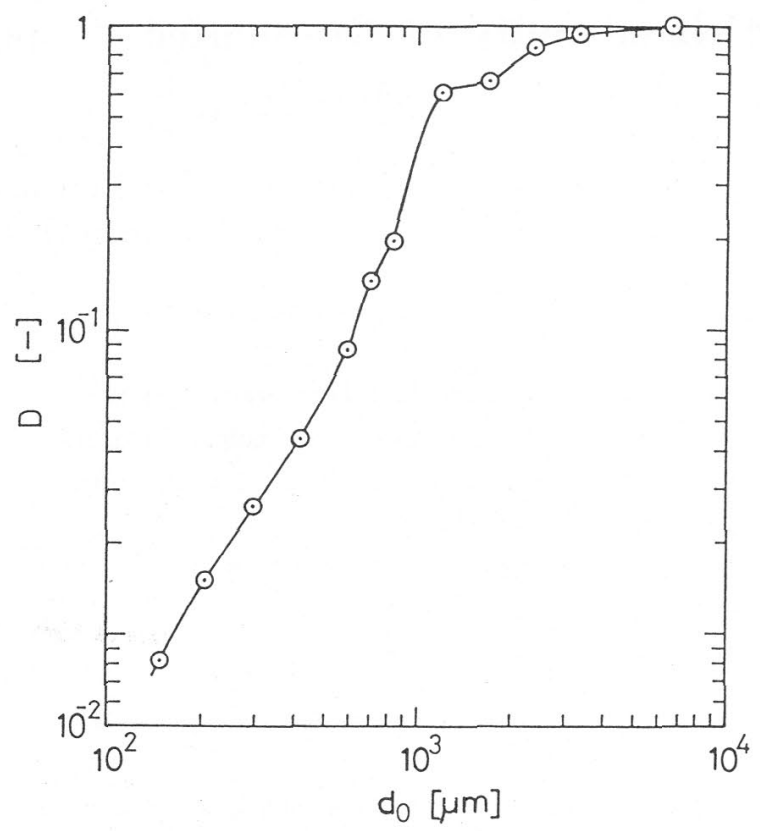

Fig. 1 Particle size distribution of the original slag samples.

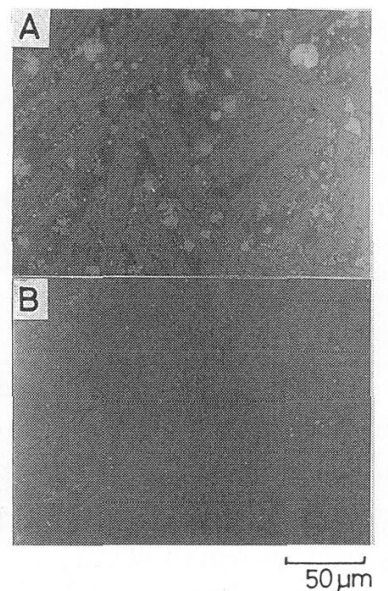

Fig. 2 Photo-micrographs of polished sections of the present slag samples. (A) over $4000 \mu \mathrm{m} \quad$ (B) $1680 \sim 2380 \mu \mathrm{m}$

compressed. Strain energy, $E$, stored in a particle until the fracture starts is defined in the following form.

$$
E=\int_{0}^{4} P d \Delta
$$

Where in Eq.(2), $\Delta$ is the deformation of a specimen. The value of $E$ is estimated from the compression test. For the relationship between $S t$ and $E$, the following equation can be derived from the theory of the materials dynamics. ${ }^{2}$ )

$$
E / M=0.897^{2 / 3} \rho^{-1}\left[\left(1-\nu_{1}^{2}\right) / Y_{1}+\left(1-\nu_{2}^{2}\right) / Y_{2}\right]^{2 / 3} S t^{5 / 3}
$$

Where, $M$ is the mass of specimen, $\rho$ the density of a sample, $\nu$ the Poisson's ratio, $Y$ the Young's modulus. Subscripts 1 and 2 denote a specimen and platens, respectively.

Corrective grinding of the slag samples was made using an alumina tumbling ball mill. The geometrical sizes of the mill are $140 \mathrm{~mm}$ in inner diameter and $140 \mathrm{~mm}$ in depth. The mass of the grinding media (alumina ball: $20 \mathrm{~mm} \phi$ ) and slag samples were kept constant at $1100 \mathrm{~g}$ and $100 \mathrm{~g}$, respectively. The rotational speed of the mill was kept at $89 \mathrm{rpm}$, which corresponds to $75 \%$ of the critical speed.

Grindability of the slag samples was determined from the particle size analysis using the JIS standard sieves, the micromesh sieves and the particle size analyzer; SA-CP2 (Shimazu Co., Ltd.). Quartz was also used in the grinding experiment in comparison with the data of the slag. The properties of the quartz can be quoted from the previous papers. ${ }^{3) 4)}$

\section{Experimental Results and Discussion}

\subsection{X-ray diffraction analysis}

The slag samples were crushed and sieved under $25 \mu \mathrm{m}$ and $\mathrm{X}$-ray diffraction profiles were measured by $\mathrm{Cu} K \alpha$ radiation with a singly-bent pyrolytic graphite monochromator in a diffracted beam in range from $2 \theta=20^{\circ} \sim 50^{\circ}$, where $\theta$ is a half of an angle between incident and diffracted beams. As a typical example, Fig. 3 shows the X-ray diffraction patterns of granulated slags with six different categories; over $4000 \mu \mathrm{m}, 2380 \sim 3360 \mu \mathrm{m}, 1680 \sim 2380 \mu \mathrm{m}, 840 \sim 1190 \mu \mathrm{m}$, $710 \sim 840 \mu \mathrm{m}$ and under $250 \mu \mathrm{m}$. The diffraction patterns of fayalite and magnetite included in the granulated slag samples agree well with the JCPDS cards $34-178$ and $19-629$, respectively. It is clearly detected that the amount of crystalline components gradually decreases as the size of the slag samples decreases and the sample, whose size lies between 710 and $1190 \mu \mathrm{m}$, is considered to be a glassy component only. This fact can be explained by the assumption that the cooling rate of the smaller particle of the slag samples is much faster than that of the larger ones. It is, however, noted that a small

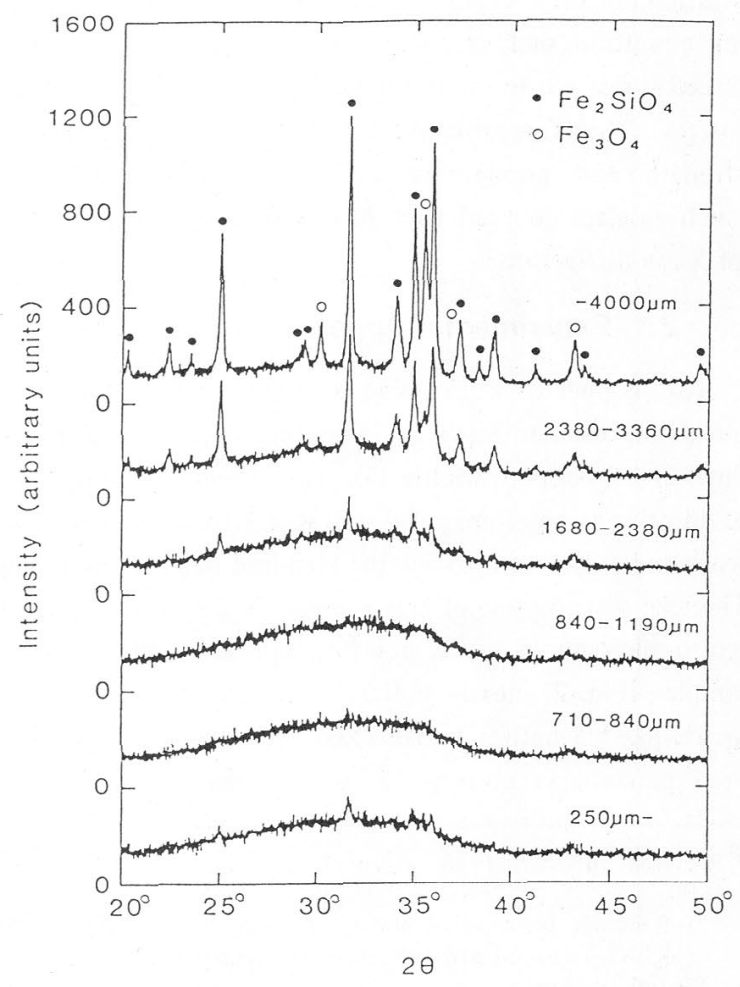

Fig. 3 X-ray diffraction patterns of the water quenched copper smelting slags for various sample sizes. 
amount of crystalline component is detected in the smallest samples with the particle size under $250 \mu \mathrm{m}$. It may be quite feasible to conclude that the smallest sample of this size is likely to be a mixture of the original as-quenched slag and the fractured products of the larger particles including a considerable amount of crystalline components. The different state of these slag samples is well attributed to the variation of the grindability, which will be described in the later section.

\subsection{Strength}

Fig. 4 gives a typical load and deformation curve of a single slag particle sieved from 10 to $20 \mu \mathrm{m}$ (the mean diameter: $15 \mu \mathrm{m})$. Fig. 5 shows the relationship between $S t$ and $E / M$ for the granulated slag samples with its original granulated particle size over $4000 \mu \mathrm{m}$ and $710 \sim 1000 \mu \mathrm{m}$, as an example. As can be seen in Fig. 5, the fracture of a single slag particle is classified into the brittle mode by finding good agreement in the gradient between the experimental data and theoretical values (Eq.(3)) expressed by the solid lines, although the experimental results are widely scattered in certain positions. Fig. 6 gives variation of $S t$ and $E / M$ of a single slag particle sieved

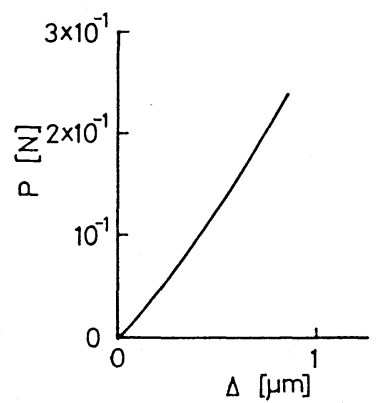

Fig. 4 Typical load and deformation curve of a single particle having a $15 \mu \mathrm{m}$ mean diameter. $\left(d_{0}=840 \sim 1190 \mu \mathrm{m}\right)$

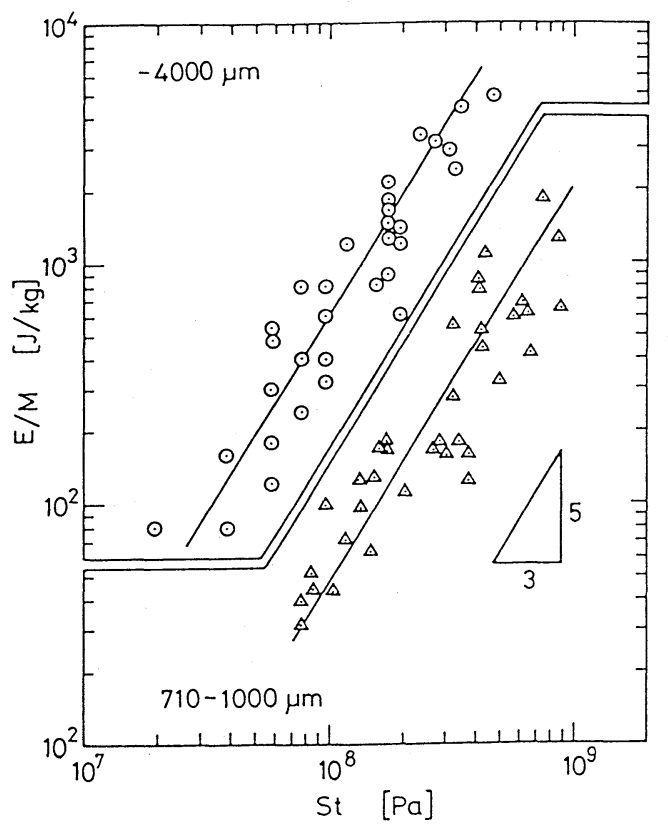

Fig. 5 Relationship between the particle compressive strength and the specific fracture energy obtained from the compression of a single slag particle having a $15 \mu \mathrm{m}$ mean diameter.

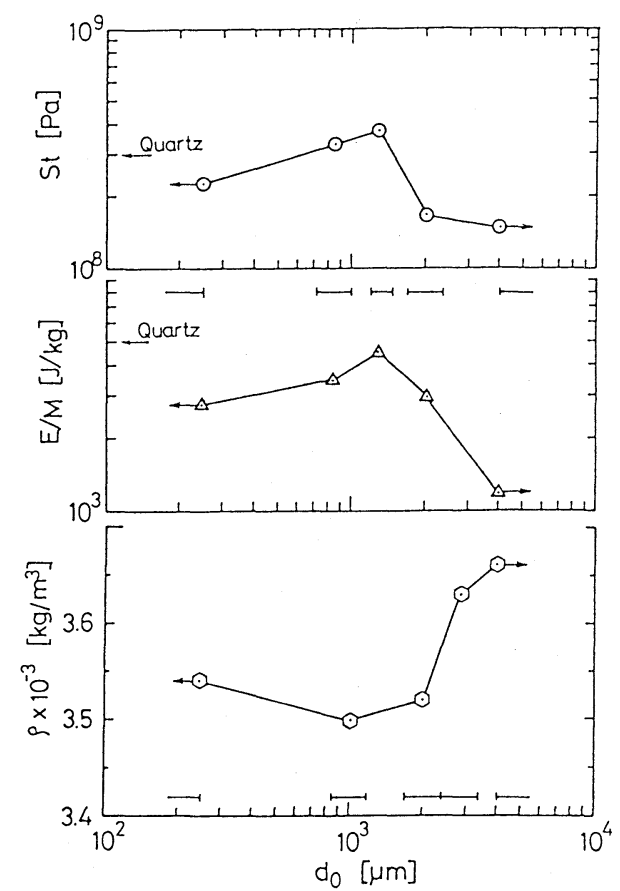

Fig. 6 Variation of the particle compressive strength, the specific fracture energy and density with the original size of slag samples.

from 10 to $20 \mu \mathrm{m}$ together with the density of granulated slags as a function of the original granulated particle size, $d_{O}$. In Fig. 6 , the data of quartz with the same particle size $(15 \mu \mathrm{m})$ are also indicated for comparison. ${ }^{5)}$ Similar correlations are well recognized in both quantities of $S t$ and $E / M$. Furthermore, the mean values of $S t$ and $E / M$ of the particles formed mainly by the glassy component were found to be much greater than those of the particles composed of crystalline components. Especially, a drastic change is observed in the mean value of strength at the vicinity of the particle size of $1500 \mu \mathrm{m}$. This is consistent with the X-ray diffraction results (Fig. 3) indicating a different combination of the glassy and crystalline components with respect to the respective particle size. Comparing the results of $S t$ and $E / M$ with those of quartz, the strength of glassy slag is equivalent to that of quartz. However, $E / M$ of the present slag samples is smaller than that of quartz. This may be due to the difference in the mechanical properties such as Young's modulus and Poisson's ratio between these two materials. Consequently, the higher strength of the slag samples with a large amount of the glassy component is appreciated in comparison with the strength of the samples with a large amount of crystalline component. Regarding to the data on the density of granulated slags, which were measured by the Archimedes' method with toluene, it was found that the density of the slag samples with a crystalline structure is higher than the glassy structure case. It may be also noted that the density varies almost inversely as a function of the original size of slag samples in comparison with the results of $S t$ and $E / M$.

\subsection{Grindability}

The results of size distribution of the fractured fragments of the granulated slag having particle sizes of $2380 \sim 3360 \mu \mathrm{m}$ 


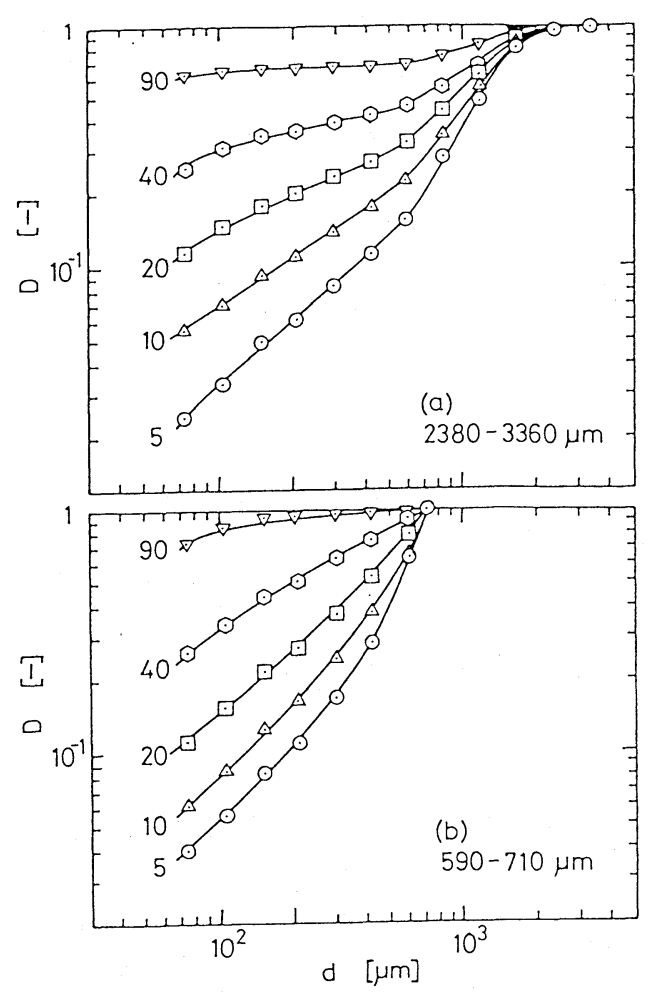

Fig. 7 Particle size distributions of ground products of slag samples by a tumbling ball mill at various grinding times.

and $590 \sim 710 \mu \mathrm{m}$ by the tumbling ball mill are shown in Fig. 7. The numerical values of $5,10,20,40$ and 90 in this figure denote the grinding time [min]. In the case of the larger particle size shown in Fig. 7(a), the slope of the straight lines on the part of fine particle range remarkably decreases as the grinding time increases. On the contrary, no significant change is detected in the slope of the straight lines for smaller particle size shown in Fig. 7(b) except for the results of 90 min. This implies that the smaller particles of granulated slag can not be easily ground in comparison with the larger ones.

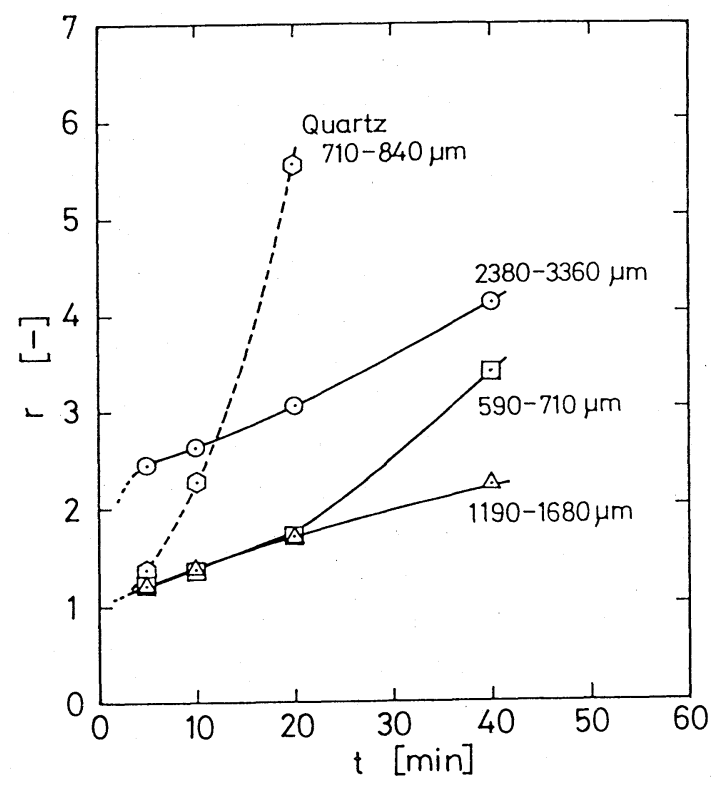

Fig. 8 Variation of reduction ratio with the grinding time for copper smelting slags and quartz.

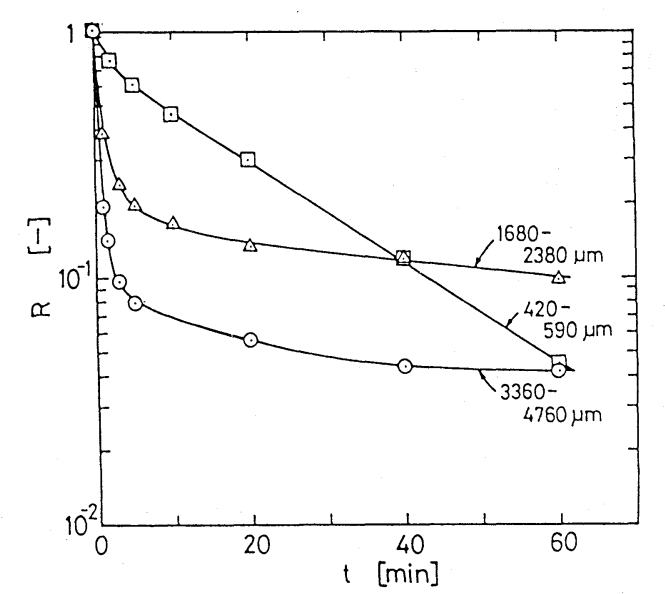

Fig. 9 Cumulative fraction retained on the stated screen size as a function of the grinding time for three sizes of slag samples.

Fig. 8 indicates the reduction ratio, $r$, defined by $\left(d_{0} / d_{50}\right)$ as a function of the grinding time for three particle sizes of the granulated slag together with the results of quartz with the particle size ranging from 710 to $840 \mu \mathrm{m}$. The reduction ratio is known to correspond to the grindability. It is generally said that the larger the reduction ratio of a sample becomes, the easier the sample is able to be ground when the grinding energies input in samples are equivalent. As shown in Fig. 8, better grindability is found in the slag samples having a larger particle size which involve a large amount of crystalline components, compared with smaller particle size consisting mainly of glassy component. However, the grindability of the slag sample is much lower than that of quartz.

The cumulative fraction, $R$, retained on the stated screen size for the slag samples with three different particle sizes is given in Fig. 9 as a function of the grinding time. The fractional rate of breakage, $k$, can be determined from the gradient of each curve in Fig. 9, depending on the grinding time. ${ }^{6)}$ The value of $k$ in two cases of $1680 \sim 2380 \mu \mathrm{m}$ and $3360 \sim$ $4760 \mu \mathrm{m}$ shows a. remarkable change with an increase in the grinding time in the initial grinding stage within a few minutes. This contrasts with the smaller particle size of $420 \sim 590 \mu \mathrm{m}$. On the other hand, in the long grinding time region, the gradient of the two curves for the cases of $1680 \sim 2380 \mu \mathrm{m}$ and $3360 \sim 4760 \mu \mathrm{m}$, apparently becomes smaller than that for the $420 \sim 590 \mu \mathrm{m}$ case. This may be attributed to the production of a large amount of fine particles during long grinding of the slag samples with the crystalline components.

\section{Concluding Remarks}

The strength and grindability of copper smelting slags produced by water quenching were tested together with the $\mathrm{X}$-ray diffraction analysis. The following conclusions of this study could be made:

(1) The granulated slag is found to be the mixture of crystalline and glassy components, amounts of which are closely related to the original particle size.

(2) The reduction ratio of a slag sample with a large amount 
of crystalline component is almost twice as large as that of a slag sample mainly composed of a glassy component. This result is well attributed to the single particle strength measurements.

(3) The density of the slag samples varies almost inversely in comparison with the results of the single particle strength measurements.

(4) The granulated slag samples in this work are not easily ground in comparison with quartz.

\section{Acknowledgements}

The authors are grateful to Mr. T. Ohkura and Mr. S. Akagi, Saganoseki Smelter, Nippon Mining Co., Ltd. for their kind supply of the granulated slag samples. The authors are also indebted to Prof. Y. Waseda for his valuable discussions and support regarding the research projects on slag. One of the authors (H.J. Ryu) wishes to thank the Ministry Education for the financial support provided through the Monbusho Scholarship.

\section{Nomenclature}

$d \quad$ : distance between two parallel platens when a particle is beginning to be compressed

$d_{0} \quad$ : original particle size

$d_{50}$ : particle size passed $50 \%$ of ground particles

$D \quad$ : cumulative fraction passing $[-]$
$E \quad$ : fracture energy

$E / M:$ specific fracture energy

$k \quad$ : fractional rate of breakage

$M \quad$ : mass of a specimen

$P \quad:$ fracture load

$r \quad$ : reduction ratio

$R \quad$ : cumulative fraction retained

$S t \quad$ : particle compressive strength

$t \quad$ : grinding time

$Y \quad$ : Young's modulus

$W_{i}$ : Bond's work index

$2 \theta$ : Bragg's angle

$\Delta \quad$ : deformation of a specimen

$\rho \quad$ : density of a sample

$\nu \quad:$ Poisson's ratio $\left[\mathrm{min}^{-1}\right]$

[min]

$[\mathrm{kWh} / \mathrm{t}]$

[ $\left.{ }^{\circ}\right]$

[m]

$\left[\mathrm{kg} / \mathrm{m}^{3}\right]$

[-]

\section{References}

1) Hiramatsu, Y., Oka, Y. \& Kiyama, H.: J. Min. \& Met. Inst. Japan, 81, $1024 \sim 1030,(1965)$

2) Timoshenko, S.P. \& Goodier, J.N.: Theory of Elasticity (3rd Edition), McGraw-Hill, New York, p. 409, (1970)

3) Yashima, S., Morohashi, S., Awano, O. \& Kanda, Y.: Kagaku Kogaku, 34, $210 \sim 219$, (1970)

4) Yashima, S., Kanda, Y., Izumi, T. \& Shinozaki, T.: Kagaku Kogaku,

[m] 36, $\quad$ 5) Sikong, L., Hashimoto, H. \& Yashima, S.: Powder Technol., 61, $[\mu \mathrm{m}] \quad 51 \sim 57,(1990)$

[ $[\mu \mathrm{m}] \quad$ 6) Kelsall, D.F., Reid, K.J. \& Restarick, C.J.: Powder Technol., 1, 291 $\sim 300,(1967 / 68)$

銅製錬水砕スラグの強度と破砕性

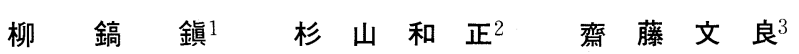

銅製錬工程において大量に排出されるシリケート系水砕スラグ について，X線回折法等によるキャラクタリゼーションを行うと ともに, 同水碎スラグの強度と破砕性について, 単粒子破砝なら びに集合粉砕の立場から実験的に検討を行った。まず，X線回折 結果では, 生成粒度約 $1.5 \mathrm{~mm}$ 以上の粗粒子はFayali te, Magnet i te の結晶質を多く含み, 粒子径が小さくなるに伴いガラス質 構造となっていることがわかった。この結果を踏まえて, 生成粒 度毎の粒子から10 20 $\mu \mathrm{m}$ (平均粒子径 $15 \mu \mathrm{m}$ ) の粒子を作製し, その強度を測定した結果, 細粒子 (ガラス質) の強度は粗粒子
( 結晶質) のそれの約 2 倍となっていること等がわかった。また， ボールミルによる粉碎実験では, 細粒子の粉砝比 (粉砕前粒度 / 粉砕後粒度) は粗粒子のそれの約 $(1 / 2)$ となっている等, 粗粒子 は細粒子に比較して破砕されやすいことがわかった。

1. 東北大学研究留学生 選鉱製錬研究所

2. 理学博士 東北大学助手 選鉱製錬研究所

3. 正会員工学博士 東北大学助教授選鉱製錬研究所

キーワード：銅製錬スラグ，強度，破砕性，X線回折

\section{資料お頒けいたします}

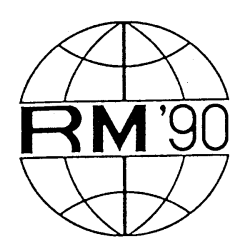

\section{Rare Metals'90}

\section{International Symposium on Processing of Rare Metals \\ Proceedings \\ of the International Symposium \\ on Processing of Rare Metals}

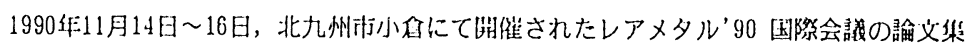

ができました。こ希望の方は本会宛八ガキまたはF a xにてお申込み下さい。

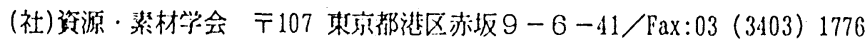

〈B $5 \cdot 464$ 頁 $\cdot 12,000$ 円（消蛽税 $\cdot$ 送料込）〉 